\title{
Social class mobility in modern Britain: changing structure, constant process
}

\author{
Lecture in Sociology \\ read 15 March 2016 \\ JOHN H. GOLDTHORPE \\ Fellow of the British Academy
}

Abstract: The class structure provides an important context for the study of social mobility. The evolution of the class structure is the all-important factor determining individuals' changing experience of mobility, as expressed in absolute rates. The total mobility rate shows long-term stability; but, because of structural change, trends of rising upward and falling downward mobility in the mid-20th century are now being reversed. Relative mobility rates, comparing the chances of individuals of different class origins arriving at different class destinations, also show long-term stability. All this is evident over a period of more or less continuous educational expansion and reform - thus calling into question the belief that educational policy is key to promoting mobility. Education is best considered as a 'positional' good; and the motivation, and capacity, of parents in more advantaged class positions to help their children maintain their competitive edge in the educational system, and in turn in labour markets, underlies the resistance to change that the mobility regime displays.

Keywords: social mobility, class structure, education, cohort studies.

\section{INTRODUCTION: THE CLASS STRUCTURE AS THE CONTEXT OF SOCIAL MOBILTY}

This lecture reports on research being undertaken by a group of sociologists, based in the Department of Social Policy and Intervention at the University of Oxford, to which I belong. Our concern is with social mobility in Britain over the period from the end of the Second World War down to the early 21st century. We focus on intergenerational mobility, and we also have a particular interest in the part that is played in such mobility by education. More specifically, we are concerned with the life-histories of men and women in a series of birth cohorts, and with how the social positions that these men and women attained in their lives are related to the positions that were held 
by their parents. The question does therefore at once arise of how 'social position' is to be understood.

We have opted to study mobility primarily in terms of positions within the social class structure. We do so because we believe that social class, as we would conceptualise it, is that form of social inequality that is most consequential for individuals' material well-being and, in turn, for a wide range of their life-chances and life-choices.

Class positions we see as being determined by the social relations in which individuals are involved in their economic lives - that is, in labour markets and workplaces; or, in short, by their employment relations. This understanding of class is in fact that which informs the main social classification in use in British official statistics since 2001: the National Statistics Socio-Economic Classification (NS-SEC). And it is on this classification that our research findings are largely based (for further details of the construction and application of NS-SEC, see Rose \& O'Reilly 1997; Rose \& Pevalin 2003; Rose et al. 2005; Office for National Statistics 2005; and for underlying theory, Goldthorpe 2007, vol. 2: ch. 5).

In Table 1 is shown the seven-class 'analytical' version of NS-SEC which is that we most often use.

Table 1. The National Statistics Socio-Economic Classification (NS-SEC): seven-class version.

\begin{tabular}{lll}
\hline \multicolumn{2}{c}{ Class description } & Salariat \\
2 & $\begin{array}{l}\text { Higher managerial and professional occupations } \\
\text { Lower managerial and professional occupations }\end{array}$ & \\
3 & Ancillary professional and administrative occupations* & Intermediate \\
4 & Small employers (less than 25 employers) and own account workers & classes \\
5 & Lower supervisory and technical occupations & \\
6 & Semi-routine occupations & Working class \\
7 & Routine occupations & \\
\hline
\end{tabular}

* NS-SEC names Class 3 simply as 'Intermediate occupations'. We elaborate on this to give a better idea of the occupations included.

In NS-SEC, occupation and employment status are taken together as indicators of employment relations, and thus of class position. At the top of the class hierarchy are the two levels of salaried managerial and professional employees-Classes 1 and 2labelled together for present purposes as the salariat; and, at the bottom come the body of wage-workers in more or less routine jobs - Classes 6 and 7-labelled as the working class. The three intermediate classes, though distinctive, need not themselves be seen as ordered. Classes 3 and 5 comprise positions with 'mixed' employment relations - that is, ones involving various compromises between the conditions of employment typical of salaried and of wage work; while Class 4 stands apart in being that of small employers and self-employed workers. 
The strength of NS-SEC lies in the degree to which it differentiates individuals in terms of their economic situation, which it does to a greater extent than would a focus simply on their incomes. NS-SEC is in fact quite strongly associated with income level. But, in addition, it is also associated with three other important aspects of individuals' economic lives: income security, short-term income stability, and longer-term income prospects (Goldthorpe \& McKnight 2006; Chan \& Goldthorpe 2007; McGovern et al. 2008). ${ }^{1}$

As an illustration, consider the following contrast. A wage-worker in Class 6 or 7 has a relatively high risk of job loss and especially of recurrent or long-term unemployment, has weekly earnings that often vary widely with piece-rates, shiftwork premia, the availability of overtime, etc., and, most importantly, has little prospect of real earnings progression after around age $30-35$. This person is living in a significantly different economic world from a salaried employee in Class 1 or 2 who has a relatively high degree of job security, a known amount of pay going into the bank each month, and the realistic expectation of salary increases, via incremental scales or promotion, up to age 50 or beyond.

Since, then, we take the class structure as the context for our analyses of social mobility, our starting point has to be with the 'shape' of this structure, and changes in its shape, in terms of the distributions of individuals within it, over the historical period that we cover. There are obvious difficulties in using data from before 2001 in order to establish these distributions according to NS-SEC. But it is possible to make estimates which, if only approximate in their details, are reliable enough in their essentials.

The estimated distributions of men are shown in Figure 1. As can be seen, the distributions change steadily in shape from being clearly pyramidal in form in 1951 to become more rectangular by 2011: that is, as the wage-earning working class-Classes 6 and 7 -contracts, and the managerial and professional salariat-Classes 1 and 2 -expands.

In the case of women, as shown in Figure 2, change on similar lines is apparent, if rather less strongly marked and especially as regards the growth in numbers in Class 1. The main distinctive feature is that the proportion of women in Class 3 first expands somewhat and then contracts - this reflecting, very largely, the rise and fall of the office secretary and typist.

A quite crucial point that I want now to stress, as regards understanding class mobility, is the following. If one is concerned with the extent to which individuals

\footnotetext{
${ }^{1}$ It is sometimes argued that the increasing inequality in incomes evident over recent decades has occurred to a greater extent within than between social classes. However, the most detailed analysis of the matter (Williams 2013) shows that this is not in fact the case. Increasing earnings inequality has to a predominant degree followed lines of class division.
} 


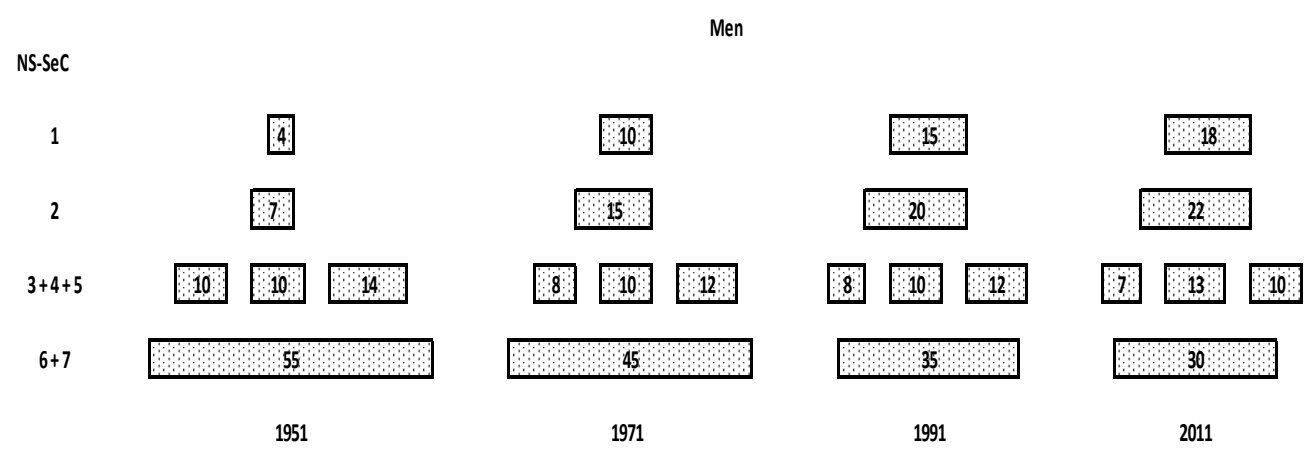

Figure 1. Class distribution (per cent) of economically active male population, 1951-2011. Source: Census and Labour Force Survey statistics; Routh (1981; 1987); Gallie (2000).

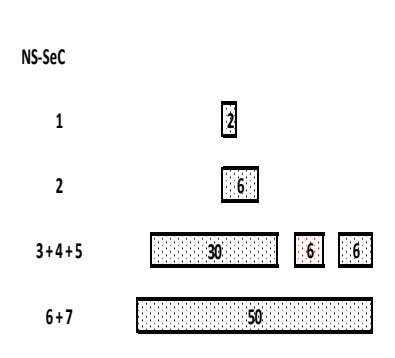

1951

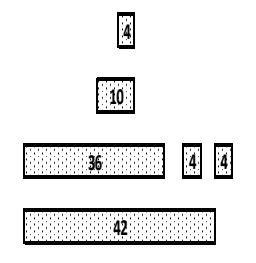

1971

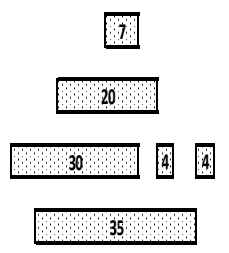

1991

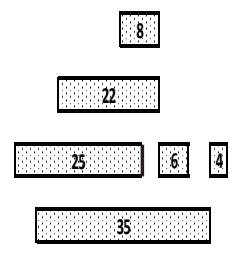

2011

Figure 2. Class distribution (per cent) of economically active female population, 1951-2011. Source: Census and Labour Force Survey statistics; Routh (1981; 1987); Gallie (2000).

actually experience mobility or immobility, and mobility upward or downward - what sociologists refer to as absolute mobility rates - then it is the class structure, and change in this structure, that are the all-important factors.

\section{ABSOLUTE RATES OF CLASS MOBILITY}

To best bring out the force of the point I have just made, I need, first of all, to go back to a period prior to that covered in our current research. Figure 3 presents some results from the Oxford Mobility Study of 1972. What is shown are absolute mobility rates for four 'quasi-cohorts' - or in effect age groups - of men who were interviewed in 1972 and born in the four 10-year periods indicated. In this case, the rates are calculated on the basis of only three, ordered, classes: the managerial and professional salariat, intermediate classes, and the wage-earning working class. 


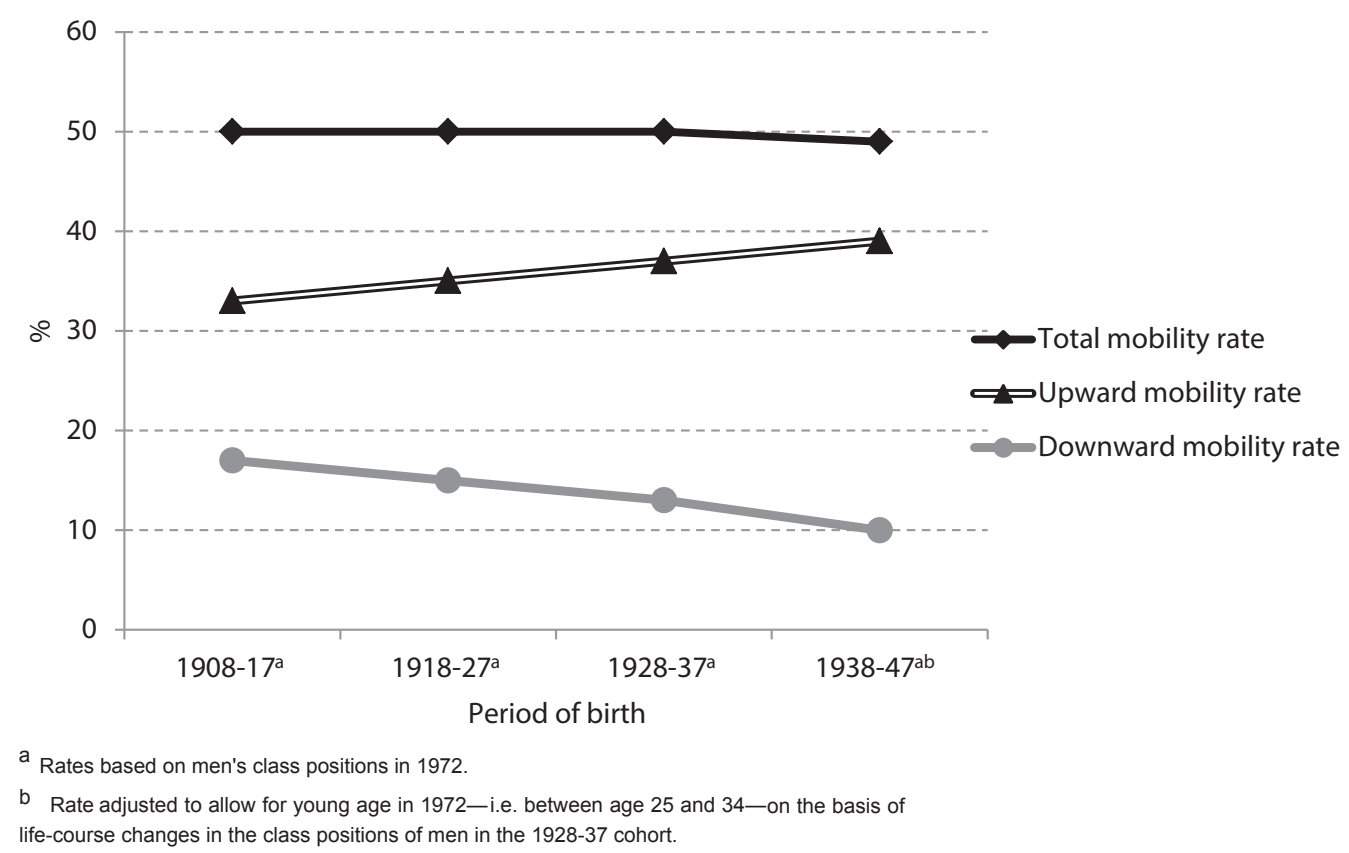

Figure 3. Total mobility rate and upward and downward components, men born 1908-47, interviewed in 1972. Source: Goldthorpe (1987).

The total mobility rate, as plotted in Figure 3, is simply the percentage of men who, in 1972, were found in a different class from that of their father. As can be seen, this rate is remarkably stable among the men covered, at around 50 per cent. However, when the total rate is divided into its upward mobility component and its downward mobility component, a clear pattern of change is evident. Upward mobility steadily increases among men born later, while downward mobility decreases. In this sense, each 'generation' fared better in its experience of class mobility than did its predecessor.

These trends can then be directly related to the steady 'upgrading' of the class structure that is shown in Figure 1: that is, to the rise of the salariat - creating ever more 'room at the top'-and the corresponding decline of the working class. It was this evolution of the class structure that created, in the middle decades of the last century, what has been aptly called the 'Golden Age' of social mobility, when social ascent clearly predominated over social descent. The key driving forces at work were, on the one hand, the growing demand for managerial and professional personnel in corporate business, central and local government, and the welfare state; and, on the other hand, the falling demand for manual workers, especially in the extractive and manufacturing industries, resulting from technological advance and changing patterns of international trade. And what may in contrast be noted, since it will be of relevance later, is the very limited part that was played by education - if only because among those cohorts who chiefly benefited from the Golden Age, education was still 'thin on 


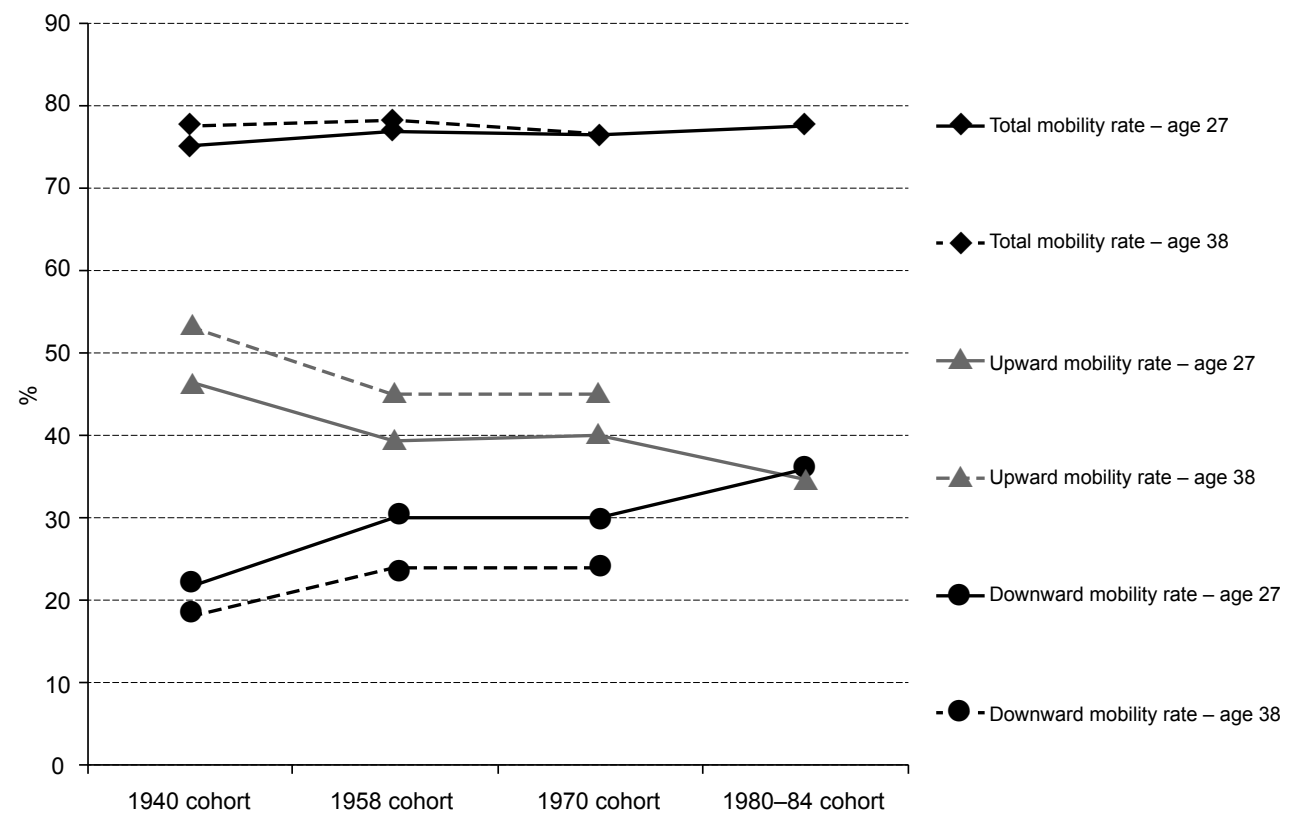

a Upward and downward rates do not sum to the total rate. Excluded is mobility among Classes 3,4 , and 5 which is treated as 'horizontal' mobility.

Figure 4. Total mobility rate and upward and downward components, men born in 1946, 1958, 1970 and 1980-84 at age 27 and (three earlier cohorts) age 38. ${ }^{\text {a }}$ Source: Bukodi et al. (2015).

the ground'. Secondary education was far from universal and tertiary education restricted to a very small minority (Halsey 2000; Smith 2000). One rather striking illustration of this point is provided by a more detailed finding from the 1972 mobility study: among men in managerial positions at that date, almost a half had no formal educational qualifications at all (Goldthorpe 1982: Table 2).

We can now turn to comparable findings from our current research (see further Bukodi et al. 2015; 2016). In Figure 4 are shown, in the same format as in Figure 3, total mobility rates and their upward and downward components for men in fourtrue - birth cohorts of 1946, 1958, 1970, and 1980-4 as determined at age 27 and, for the three earlier cohorts, also at age $38 .^{2}$

It can be seen that the total mobility rate is higher than in Figure 3, at almost 80 per cent. But this is simply because we are here using the seven-class NS-SEC, as in Table 1, as the basis of our analyses rather than a three-class schema: there are just

${ }^{2}$ The first three of these cohorts are the first three in the now well-established series of British birth cohort studies (see further Pearson 2016), on the datasets of which we draw: i.e. the 1946 MRC National Survey of Health and Development, the 1958 National Child Development Study, and the 1970 British Birth Cohort Study. The 1980-4 cohort is one that we have ourselves constructed on the basis of data from the first wave of the UK Household Longitudinal Study ('Understanding Society') carried out between 2009 and 2011. 


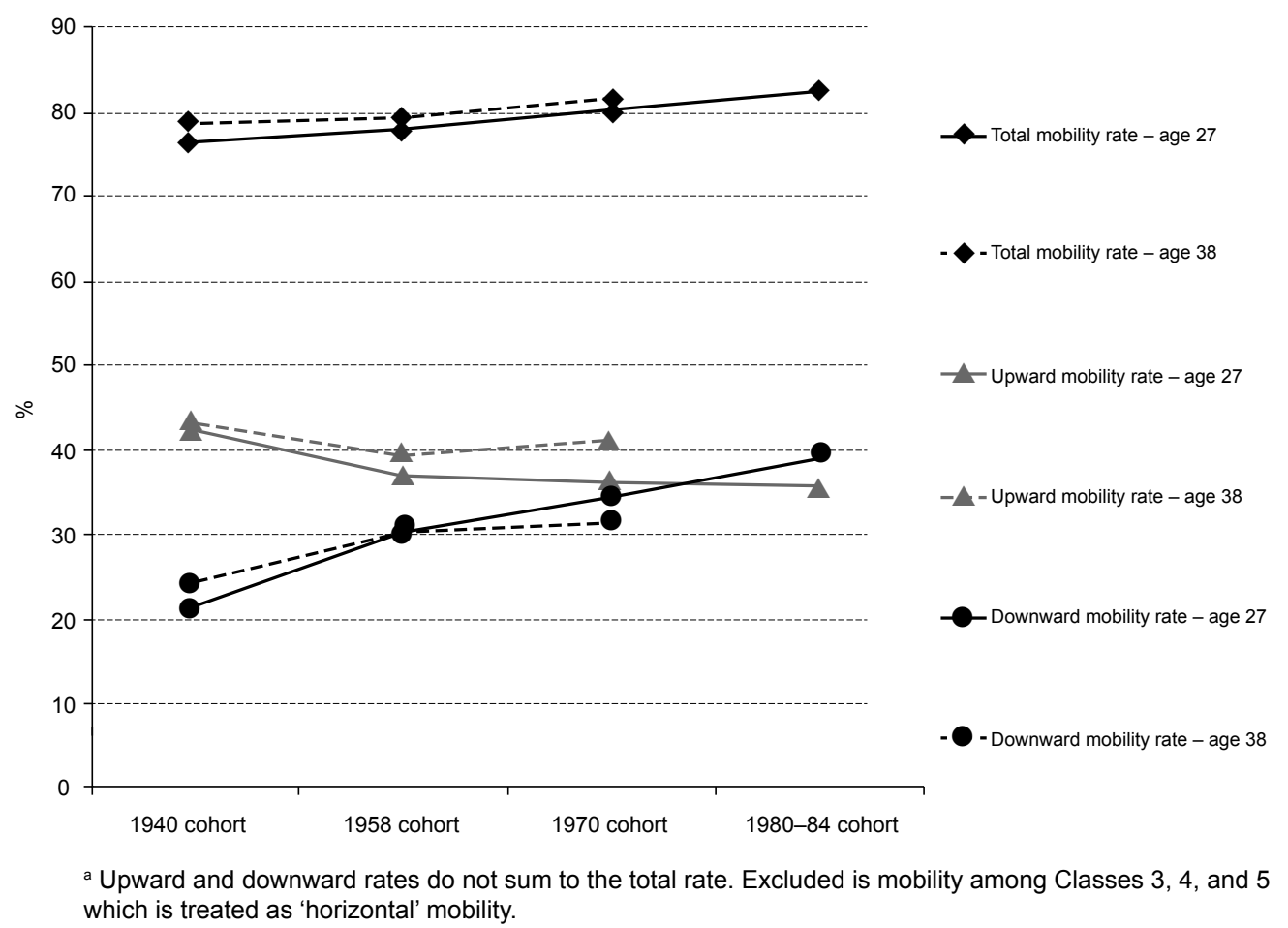

Figure 5. Total mobility rate and upward and downward components, women born in 1946, 1958, 1970, and 1980-84 at age 27 and (three earlier cohorts) age 38. ${ }^{\text {a }}$ Source: Bukodi et al. (2015).

more classes to move between. The important points are these. First, the total rate is, as before, essentially stable. But, second, there is now a reversal in trend in the upward and downward components of the total rate. Over these cohorts, it is the upward component that is tending to decrease, and the downward component to increase.

In Figure 5 we show corresponding results for women. The total mobility rate does in this case tend slightly to rise, from a little below to a little above 80 per cent, for reasons that will subsequently emerge. However, its upward and downward components still move in much the same way as with men.

What this means, then, is that a situation is emerging that is quite new in modern British history, and one that could have far-reaching sociopolitical consequences. There is no decline in mobility overall, contrary to what politicians and the commentariat so often tell us. ${ }^{3}$ But what is happening, and what has been largely overlooked, is

${ }^{3}$ The notion of social mobility in decline was one that gained wide acceptance, in favourable political circumstances, following an analysis of intergenerational income mobility, based on the 1958 and 1970 cohorts, made by a group of economists (Blanden et al. 2004). However, subsequent research on income mobility (Nicoletti \& Ermisch 2007) covering a longer period is more consistent with the idea of little change, and the question of the relationship between the earlier findings and those onclass mobility has 
that younger generations of men and women now face less favourable mobility prospects than did their parents - or their grandparents: that is, are less likely to experience upward mobility and more likely to experience downward mobility.

How has this situation come about? The answer is that it represents the 'dark side' of the class structural change that created the previous Golden Age of social mobility. As a result of the expansion of the salariat in the last century, increasing numbers of individuals are now starting out in life from more advantaged class positions. Consistent with the general direction of change in the shape of the class structure as shown in Figures 1 and 2, we find that between our 1946 and 1980-4 cohorts the proportion of men and women originating in Classes 1 and 2 tripled, while the proportion originating in Classes 6 and 7 halved (Bukodi et al. 2015: Table 1). Thus, the numbers of those 'at risk' of downward mobility are steadily rising, and the numbers 'at risk' of upward mobility are steadily falling. And what lies behind the graphs of Figures 4 and 5 is this structurally induced change in numbers at risk rather than any changes in the relative chances of upward or downward mobility of individuals of different class origins.

Indeed, what I now want to go on to show is that relative mobility chances-or, that is, relative as opposed to absolute rates of class mobility-are characterised, just like the total mobility rate, by a large degree of constancy over time.

\section{RELATIVE RATES OF CLASS MOBILITY}

What relative rates of social mobility aim to capture are the chances of individuals of different classes of origin being found in different classes of destination when all effects of class structural change are discounted. Another way of putting this would be to say that relative rates are concerned with the net association-the inherent 'stickiness' - that exists between the class positions of children and their parents.

In mobility research, this net association is measured by what are known as odds ratios. Suppose we have a society with only two classes, $a$ and $b$, and that we construct a fourfold mobility table in which individuals are cross-classified according to their class of origin and class of destination. The odds ratio that we can calculate is then:

$$
\frac{F_{a a} / F_{a b}}{F_{b a} / F_{b b}}
$$

where $F$ stands for frequency.

become a matter of rather complex debate (see Erikson \& Goldthorpe 2010; Blanden et al. 2013; Goldthorpe 2013). 
What this odds ratio tells us is the chance of an individual originating in class $a$ being found in class $a$ rather than in class $b\left(F_{a a} / F_{a b}\right)$ relative to the chance of an individual originating in class $b$ being found in class $a$ rather than in class $b\left(F_{b a} / F_{b b}\right)$. If the odds ratio works out at 1 , this means that these chances are equal, and that there is no association between class origin and destination. But as the odds ratio rises above 1 , the more unequal are the relative chances, and the stronger the association between class of origin and of destination. ${ }^{4}$

Odds ratios are a valuable statistic in mobility research in 'netting out' the effects of structural change. ${ }^{5}$ But a problem does arise. With just two classes in the analysis, there is, as shown above, only one odds ratio to be calculated. However, as the number of classes to be considered increases, so too does the number of odds ratios involved, and at a rapid rate. There is one odds ratio for every possible pair of origin classes taken together with every possible pair of destination classes. Thus, when mobility is analysed on the basis of the seven NS-SEC classes, there are in all $(7 \times 6) / 2$ origin classes to be taken together with $(7 \times 6) / 2$ destination classes or, in all, $21^{2}=441$ odds ratios that could be calculated.

In this case, then, in treating relative mobility rates via odds ratios, we have to resort to statistical models: that is, to models that make statements about what is happening to odds ratios, which statements can then be tested against the empirical data. In our analyses, we rely primarily on two such models.

The first model is known as the constant social fluidity, or CSF, model. What this says is that across the mobility tables for our birth cohorts-i.e. sevenfold tables based on NS-SEC - all corresponding odds ratios are the same from one cohort to another. In other words, the net association - the inherent stickiness - between the class positions of children and their parents is unchanging or, put the other way around, the degree of social fluidity within the class structure is at a constant level.

The second model is known as the uniform difference, or UNIDIFF, model. What this says is that, from cohort to cohort, the odds ratios underlying our mobility tables all change by some common multiplicative factor - the parameter for which is labelled as $\beta$. If $\beta$ is set at 1 for a particular cohort and then moves below 1 for the next cohort, this means that all odds ratios are decreasing - i.e. the association between class

\footnotetext{
${ }^{4}$ It would of course be mathematically possible for an odds ratio to fall below 1, but this would be rather unlikely in any actual society, except perhaps in one in the throes of revolution, since it would imply a negative association between class of origin and of destination.

${ }^{5}$ They can do this because they provide what is known as a 'margin-insensitive' measure of association. Thus, with a series of mobility tables in which individuals are cross-classified by class of origin and of destination, odds ratios will be unaffected by any changes in the distributions of class origins and destinations, as shown in the table 'margins'.
} 
origins and destinations is weakening and social fluidity is rising. If $\beta$ moves above 1 , the reverse is the case. ${ }^{6}$

How, then, do these two models fare when we set them against our data? I focus here on results for the first three of our cohorts, where we can take class destinations at age 38. By this age we know that individuals' class positions become relatively stable (Bukodi \& Goldthorpe 2009; 2011).

With men, the CSF model fits the data quite well, and the UNIDIFF model makes no significant improvement on it. In Figure 6, on the left-hand side, a plot is given of the $\beta$ parameters under the UNIDIFF model. It can be seen that $\beta$ rises very slightly as between the 1946 and 1958 cohorts and then falls between the 1958 and 1970 cohorts. What is, however, more important is that the 95 per cent confidence intervals around the point estimates overlap a good deal, and this is why the CSF model is preferred. The hypothesis that it embodies of no change in fluidity cannot be safely rejected.

With women, the CSF model again gives an acceptable fit to the data by conventional standards but, in this case, UNIDIFF does provide a significant improvement. The plot of the $\beta$ parameters on the right-hand side of Figure 6 shows that these fall across the cohorts, and there is no overlap in the confidence intervals around the point

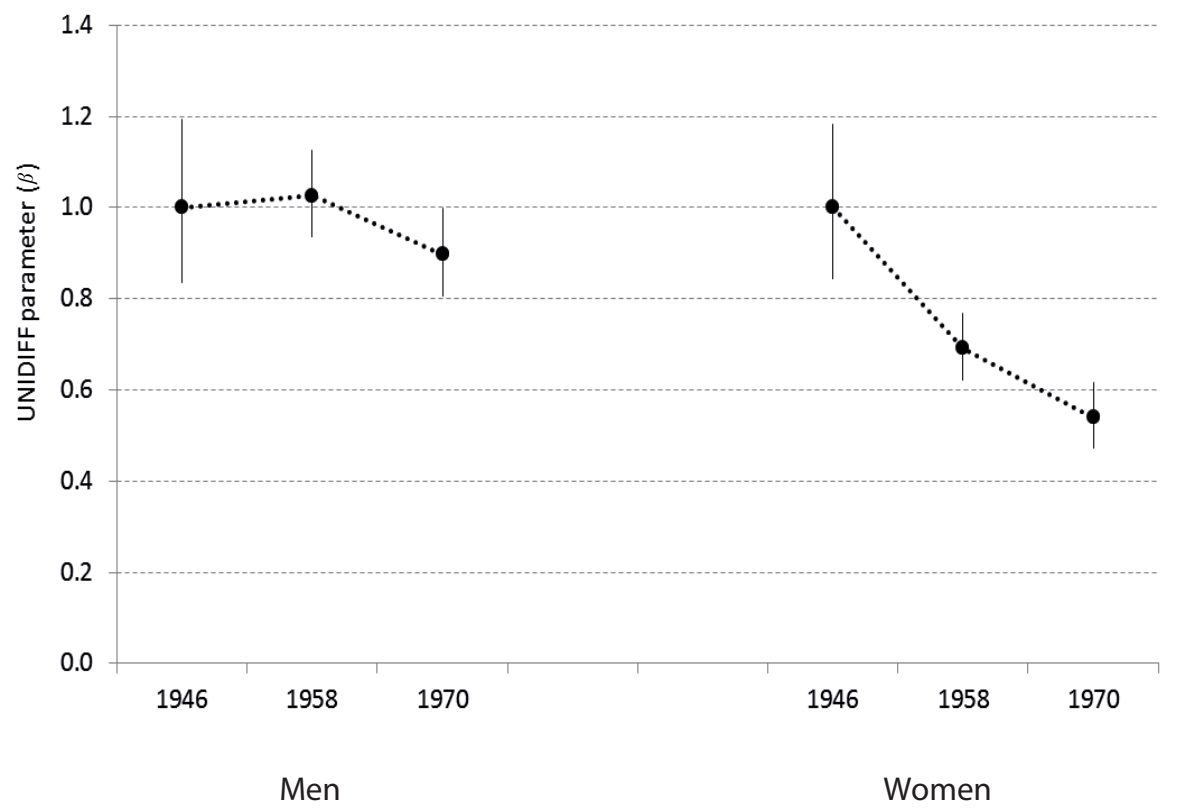

Figure 6. $\beta$ parameters under the UNIDIFF (uniform difference) model (with $95 \%$ confidence intervals) for 1946, 1958, and 1970 cohorts, men and women at age 38. Source: Bukodi et al. (2015).

${ }^{6}$ Technically, the CSF model is a log-linear model and the UNIDIFF model a log-multiplicative model. Formal statements of both models, as applied to our mobility tables, can be found in Bukodi et al. (2015: 14-15). For a general review of the statistical modelling of mobility tables, see Breen (2004). 
estimates. In other words, among women, the association between their class origins and class destinations can be taken as weakening; social fluidity is increasing. ${ }^{7}$ And it is this that accounts for the increase in the total mobility rate among women that was shown in Figure 5.

The gender difference that is revealed here is of obvious interest, and we have explored it in some detail (Bukodi et al. 2016). Two main findings emerge. First, it turns out that the increase in fluidity among women is not general. It is in fact confined to those women who at some point have worked part-time. Among women who have worked only full-time, and even if with one or more periods of absence from the labour market, we get the same result as for men: the CSF model is preferred. Second, women who have worked part-time would appear to be in some degree self-selected. They do not differ from women who have worked only full-time in their class origins, nor, in any consistent way, in their educational level. But they do differ in being more likely to take up low-grade jobs when they first enter the labour market - often ones in Classes 6 and 7 -and even if they are not at that point working part-time.

Now these findings regarding the sources of increased fluidity among women are, I believe, of some larger consequence, and I shall come back to them. But, this rather special case apart, the most notable outcome of our analyses of relative rates of class mobility is the degree of constancy that is revealed. It should in this connection be said that the results we obtain are not in fact all that surprising. They are much in line with - and serve therefore primarily to update - those of a good deal of earlier research that has likewise indicated little change in levels of social fluidity within the class structure, and indeed over a historical period that extends back to comprise the Golden Age of mobility (Goldthorpe 1987; Goldthorpe \& Mills 2004; 2008; Paterson $\&$ Ianelli 2007). The point is thus underlined that the Golden Age should be seen not as the consequence of Britain becoming in any sense a more 'open' society but, in just the same way as its less benign present-day sequel, as being the outcome of class structural change.

There is, though, one further respect in which our analyses of relative rates do make an advance. In using NS-SEC as the basis of these analyses, we are able, while confirming the long-term stability of these rates, also to arrive at more reliable estimates than were previously possible of the degree of the inequalities in mobility chances that are entailed (see further Bukodi et al. 2015: 17-19).

If, for example, we take together Classes 1 and 2, the salariat ( $s$ ), and Classes 6 and 7 , the wage-earning working class $(w)$, and on this basis consider the odds ratio:

${ }^{7}$ Full details of the statistics of fit of both models in their application to cohort mobility tables for men and women are given in in Bukodi et al. (2015: Tables III and IV). 


$$
\frac{F_{s s} / F_{s w}}{F_{w s} / F_{w w}}
$$

what we find is that, for men, this works out for each cohort alike at approximately 6 . That is to say, over the period we study, the chances of men born into the salariat ending up in the salariat rather than in the working class are around six times greater than the chances of men born in the working class ending up in the salariat rather than in the working class. For women, the odds ratio is declining somewhat, with the increase in fluidity that we have shown, but still averages across the cohorts at around 5. I can only regard these inequalities as unacceptably extreme, and what may further be noted is that they appear greater than the analogous inequalities that show up if mobility is treated on the basis of income (see, e.g., Erikson \& Goldthorpe 2010: Table IV; Goldthorpe 2013: Table 1). In other words, taking class as the context of mobility allows for a fuller understanding of the extent of the intergenerational transmission of economic advantage and disadvantage. ${ }^{8}$

To sum up so far, our research reveals a high degree of constancy in relative rates of class mobility, just as was found in the total absolute rate (albeit with a striking reversal of trend in its upward and downward components). It is therefore again important to say that there has in no way been a decline in mobility. But neither, one might equally well say, is there evidence of any increase, at least of a general and significant kind. And viewing our results in this latter perspective serves to bring into rather sharp focus the further question of interest to us - that of the role of education in social mobility. It is widely believed, and especially in political circles, that education plays a quite crucial part in social mobility processes. Successive governments, committed to increasing mobility, have regarded educational policy as the essential means to this end. But how does this view square with fact that the stability in mobility rates that we can demonstrate extends over a historical period in which educational expansion and reform have been more or less continuous-from the Butler Act of 1944, introducing free secondary education for all, through the shift from selective to comprehensive secondary education, to the rapid expansion of tertiary education in the 1960s and again in the 1990s?

Education is, without doubt, a major factor in determining who is mobile or immobile - which individuals. But it in no way follows automatically from this that

\footnotetext{
${ }^{8}$ If we consider the odds ratio involving only Class 1 , the higher stratum of the managerial and professional salariat, and Class 7, the lower stratum of the working class, then, as might be expected, a still greater degree of inequality is evident. Although the smaller numbers involved reduce the reliability of estimates, the odds ratio for men is in this case best placed at around 20 and for women at between 20 and 15, though again with a declining tendency. A statistical model of how such inequalities in relative mobility chances are actually generated in the context of the class structure is provided in Bukodi et al. (forthcoming).
} 
education will be of similar importance in determining the total amount of mobility at the societal level. So why is education believed to be so crucial in this latter respect, and how well founded is this belief?

\section{THE ROLE OF EDUCATION IN SOCIAL MOBILITY}

Sociologists tend to discuss the role of education in social mobility in terms of what is called the 'OED triangle': that is, the triangle of associations between origins, education, and destinations. Figure 7 shows one version of the triangle that expresses what might be called the 'liberal' view that education is key to social mobility.

According to this view, educational expansion and reform create a greater equality of educational opportunity and attainment, and thus weaken the origin-education (OE) association. At the same time, the pressures of economic efficiency and technological advance make for more 'meritocratic' selection in labour markets: that is, selection based on formal educational qualifications - thus strengthening the education-destination (ED) association. In turn, the 'direct' OD association, that which is not mediated via education, weakens, and so too then does the overall OD association. In other words, relative rates of mobility become more equal and social fluidity increases.

But how far has this scenario been realised in the British case? Figure 8 shows another version of the OED triangle that reflects the most frequent findings of previous research where social origins and destinations are treated in terms of class.

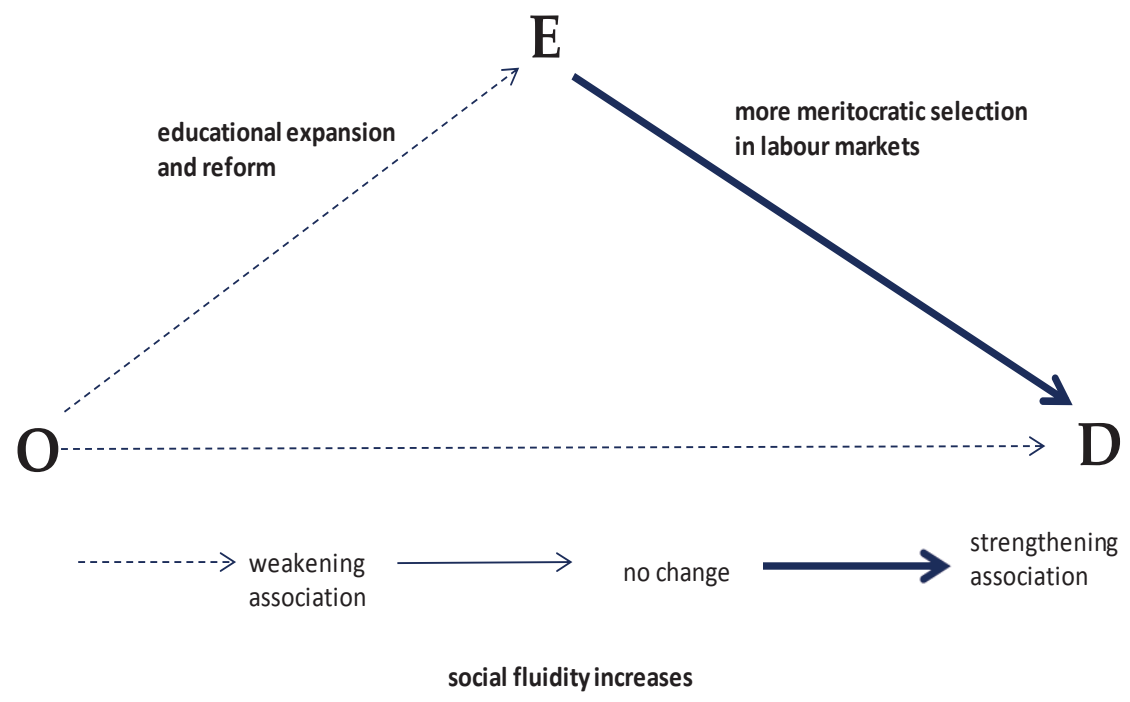

Figure 7. The OED (origins, education, and destinations) triangle: the liberal view. 


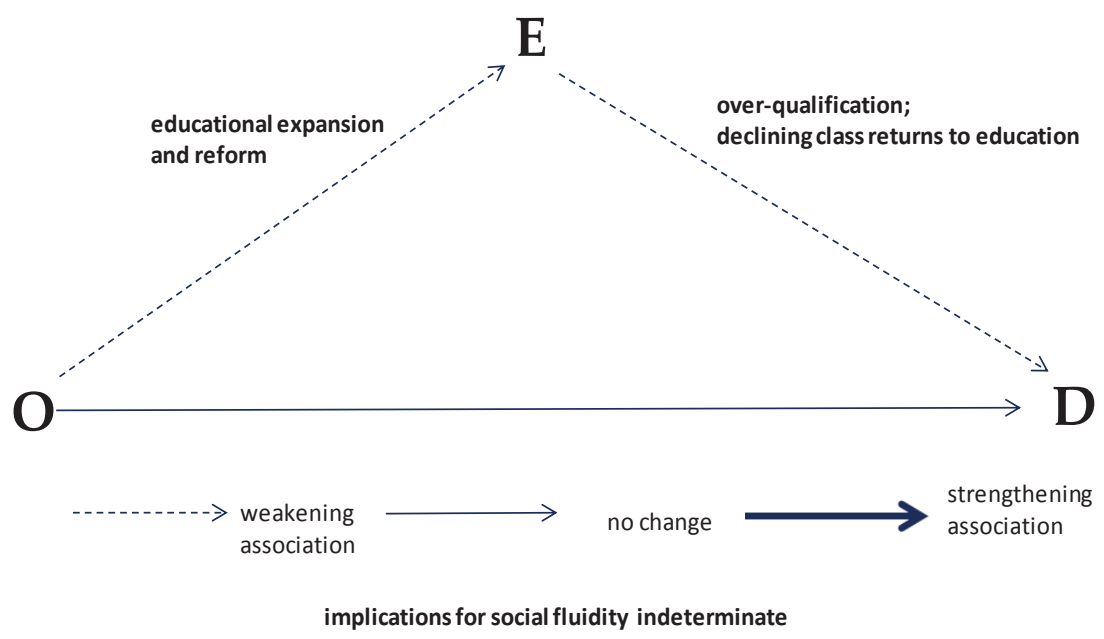

Figure 8. The OED (origins, education, and destinations) triangle: typical results from class mobility research.

Most, though not all, investigators do find that inequalities in educational attainment related to class origins have narrowed, even if only slightly and mainly at lower educational levels (see, e.g., Jonsson \& Mills 1993; Breen et al. 2009; 2010). So, in this regard a degree of support for the liberal view exists: the OE association would appear to weaken somewhat. But at the same time it has been quite regularly found that the ED association does not strengthen but in fact tends also to weaken (Goldthorpe \& Mills 2004; Jackson et al. 2005; Goldthorpe \& Jackson 2008). This can be attributed to the increasing supply of the higher educated outstripping demand, and also perhaps to employers, in a context of 'credentials inflation' increasingly applying a range of other selection criteria. At all events, the graduate job would now appear to be a fast-fading concept; and a situation of over-qualification at the graduate level in turn results in the 'bumping down' of the labour-market value of all lower-level qualifications.

These results are then problematic in their implications, and especially as there is no evidence of any change in the direct OD association (Vandecasteele 2016; cf. also Gugushvili et al. 2016). What is suggested is that any equalisation in educational attainment that may have been obtained in relation to class origins is being offset by a decline in the 'class returns' that education brings.'

To try to throw more light on this matter, we have reconsidered the way in which education is conceptualised and measured in mobility research. Usually, education is

${ }^{9}$ The finding of declining class returns to education is by no means restricted to Britain. It is widely reported in studies made across modern post-industrial societies (see, e.g., Breen \& Luijkx 2004: 390-5). 
treated in what might be called absolute terms, and is measured according to years of education completed or highest level of qualification achieved. However, if education is to be regarded primarily as an investment good, in regard to the labour market, rather than as simply a consumption good, it would seem more appropriate to treat education as being also a positional good (Hirsch 1977), and to measure it, therefore, in relative terms. On this view, what matters is not just how much education an individual has but how much relative to others - and especially relative to those others who will be most direct competitors in the labour market.

Across the birth cohorts we study, we have therefore measured educational qualifications by two kinds of scale: by an absolute scale in which formally similar qualifications are placed at the same level for members of each cohort alike; but also by a relative scale in which how qualifications are scored depends on the distribution of qualifications within a particular cohort. So, for example, with our relative scale, A-levels in the 1946 cohort count for more than do A-levels in the 1970 cohort, within which far more individuals hold them (for further details, see Bukodi \& Goldthorpe 2016).

The findings we obtain, so far only for men, are as follows. Figure 9 relates to the association between class origins and educational attainment or, that is, to the OE side of the OED triangle. It shows changes in this association across our cohorts again as measured by the $\beta$ parameter under a form of the UNIDIFF model. It can be seen that with our absolute scale of education we find, just as others have done, some weakening in the $\mathrm{OE}$ association or, that is, a reduced effect of class origins on educational attainment. But with our relative scale, although the $\beta$ point estimates do fall slightly, the large overlap of the confidence intervals around these points means that 'no change' is the safest conclusion.

Figure 10, with the same format as Figure 9, then relates to the association between education and class destinations or, that is, to the ED side of the OED triangle. Again with the absolute scale of education, we find, like others, a weakening association or, in other words, declining class returns to education. But with the relative scale we again have a different outcome: one indicating no clear trend of change-only what would appear to be trendless fluctuation, reflecting, one might think, varying labour-market conditions.

If, then, we take our results when using what seems to us, for the analyses in question, to be the more appropriate, relative educational scale, another empirically grounded version of the OED triangle is suggested, as is shown in Figure 11. In this case, there is no change, or at least no directional change, on any of the three sides of the triangle, nor then in the overall OD association - in line, that is, with our finding of an essential constancy in relative rates. What might be called 'the endogenous mobility regime' appears essentially stable over time. 


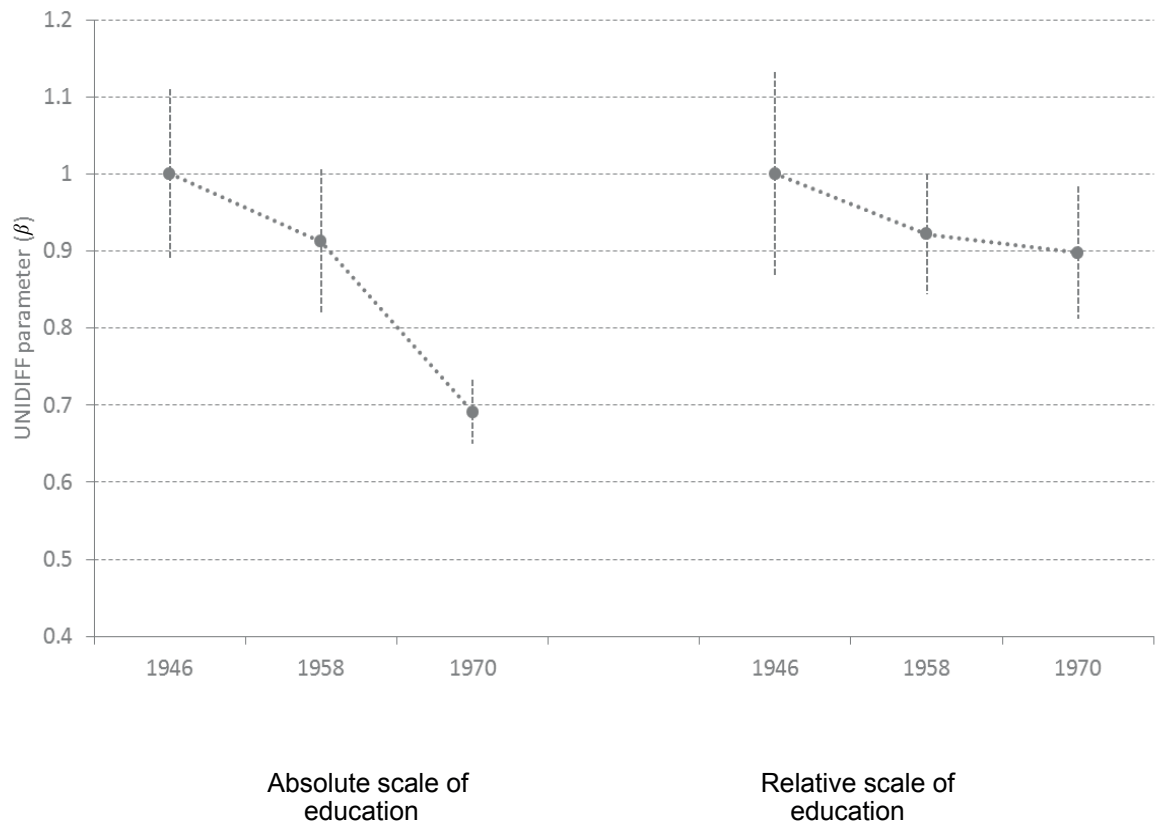

Figure 9. The OE (origin-education) association over three cohorts with education measured on absolute and relative scales, men, $\beta$ parameters. Source: Bukodi \& Goldthorpe (2016).

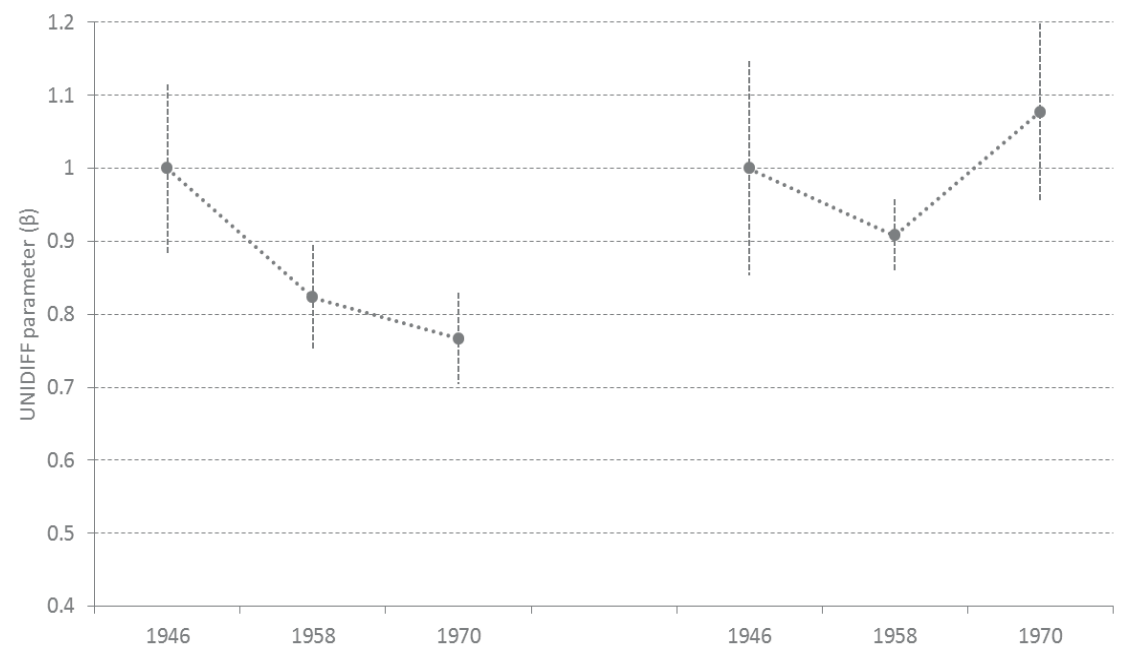

Absolute scale of education

Relative scale of education

Figure 10. The ED (education-destination) association over three cohorts with education measured on absolute and relative scales, men, $\beta$ parameters. Source: Bukodi \& Goldthorpe (2016). 


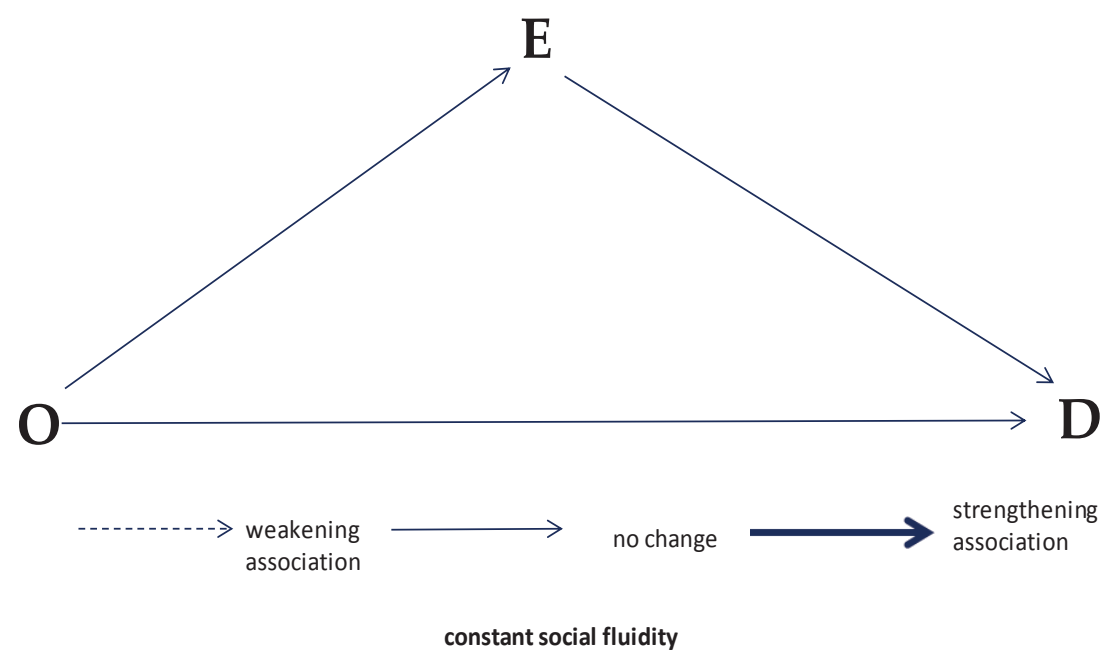

Figure 11. The OED (origins, education, and destinations) triangle: empirical findings with education measured in relative terms.

If this conclusion is accepted, two questions obviously arise: how is this stability to be explained, and why have decades of educational expansion and reform had so little effect?

One important part of the answer, I would suggest, is that parents and their children do themselves understand education in relative terms. And parents in more advantaged class positions will not then simply be passive in relation to the expansion or reform of the educational system but will respond by using their own superior resources - economic, cultural, and social - to whatever extent it takes to help their children retain a competitive edge in the system, and in turn in the labour market (cf. Francis and Hutchings 2013). It has, moreover, to be recognised that, even if children from more advantaged backgrounds do not do well educationally before entering the labour market, at least permanent downward mobility can still often be forestalled. Parental social contacts and networks may play a part here. But far more important, our research suggests (Bukodi 2016; Gugushvili et al. 2016), is the fact that the more advantaged individuals' backgrounds, the more likely they are to gain further qualifications over the course of their working lives, and especially so if their previous educational performance was only modest. And in this case then, in helping to reverse any initial downward mobility, further education clearly serves to promote intergenerational immobility.

The nub of the matter is this. If relative mobility rates are to become more equalif odds ratios are to move closer to 1 - this means, as a mathematical necessity, that downward mobility has to increase just as much as upward mobility. But, as against this 
mathematical symmetry, there is a psychological asymmetry. Consistently with the theory of 'loss aversion' (Kahneman 2011: ch. 26), families may be regarded as being yet more concerned with the avoidance of downward mobility than they are with the achievement of upward mobility. And the resources of those families with most to lose through downward mobility will, in the nature of the case, tend to be greater than the resources of families with most to gain through upward mobility (see further Goldthorpe 2007: chs. 3, 4, and 7). It is, then, this coming together of the strong motivation to avoid déclassement and the usually adequate means for so doing that, in my view, is the main source of the very powerful resistance to change that the endogenous mobility regime displays.

In this regard, our finding of some increase in social fluidity among women who have worked part-time is instructive. As I said earlier, these women would appear to be in some degree self-selected. And fluidity increases because a growing number of them coming from relatively advantaged class origins do not pursue the kinds of career that their origins and their education would probably make available to them-primarily, it might be supposed, because of a prior commitment to family life. In other words, greater fluidity is created only because the women in question in effect choose to accept downward mobility so far as their own working lives are concerned-a choice that has of course to be understood in the context of existing institutional arrangements concerning childcare provision, maternity (and paternity) leave, flexible working hours, and so on. ${ }^{10}$ It has, however, at the same time to be noted that women from more advantaged backgrounds who opt for part-time work are still far more likely than their counterparts from less advantaged backgrounds to acquire husbands or partners who are in managerial or professional positions. Thus, such increase in fluidity as results is likely to be less apparent if it is the conjugal family rather than the individual that is taken as the unit of analysis (see further Bukodi et al. 2016).

\section{POLICY IMPLICATIONS}

In conclusion, I might say something, if only briefly, about what follows from our research for policy in regard to social mobility - that is, on the assumption, which some might wish to challenge, that greater mobility, or at all events greater upward mobility, is an objective to be pursued.

\footnotetext{
${ }^{10}$ While our findings are in accord with those presented by Hakim (2000) so far as the marked heterogeneity of women's orientations to work is concerned, we would not follow her in treating this heterogeneity as a matter of more or less fixed preferences, but would rather see it as resulting from life-choices being made - as is typically the case - under a variety of constraints.
} 
If the aim is to increase mobility, both upward and downward, by creating a greater equality in relative rates, the main implication is that what can be achieved through educational policy alone is limited - far more so than politicians find it convenient to suppose. The basic source of inequality of educational opportunity lies in the inequality of condition - the inequality in resources of various kinds - that exists among families with different locations within the class structure. Policies can of course be developed to try to offset the educational consequences of this inequality, from pre-school programmes for more disadvantaged children to measures aimed at creating a more socially balanced entry into elite universities. And these policies have much to commend them on educational grounds alone-in enabling children to develop their educational potential to the full. But our findings for the historical period that we cover indicate that to look to the educational system itself to provide a solution to the problem of inequality of opportunity is to impose an undue-and, I would say, an unfair - burden upon it. Rather, a whole range of economic and social policies is needed, directed towards what my old mentor, T. H. Marshall, used to call 'class abatement' (see Marshall 1950).

If, on the other hand, the aim is not so much to increase mobility overall but rather to change its pattern, and to move back to a situation, like that of the Golden Age, when upward mobility predominated over downward, then the role of education is again limited - as indeed it was in the Golden Age itself. What in this case are called for are policies that can lead to a further upgrading of the class structure: that is, policies not just for economic growth but for economic and social development that can help create more 'top-end' jobs: for example, policies aimed at improving our not very impressive record of investment in research and in its productive application and at giving a more purposive direction to technological advance (cf. Atkinson 2015: ch. 3); policies for creating a modernised and environmentally friendly infrastructure; and policies that lead to the progressive raising of the quality of all social and other public services.

This leads me to one last thought - of a clearly heretical kind. Even if greater social mobility is regarded as desirable, does this mean that its promotion should be taken as a direct concern of policy? Herbert Spencer once suggested (1873: 52), as a model for the policy maker, a craftsman - a planisher - faced with the problem of a bulge in a piece of metal sheeting. To remove it, the planisher does not hammer directly on the bulge but rather all around it. Perhaps policy makers committed to the idea of 'greater opportunity for all' would do well to focus their efforts on reducing social inequalities of condition and on creating rising demand within the economy for personnel in high-level managerial and professional roles-and then leave social mobility to look after itself. 


\section{Acknowledgements}

I am greatly indebted to Erzsébet Bukodi, the leader of the research group in which I work at Oxford, for the help that she has given me in the preparation of this lecture; and I would also like to acknowledge the contributions of other, past and present, members of the group, in particular those of Heather Joshi, Jouni Kuha and Lorraine Waller. Support for the research came from a grant from the Economic and Social Research Council, ES/103 $8187 / 1$.

\section{REFERENCES}

Atkinson, A. B. (2015), Inequality: What Can be Done? (Cambridge, MA, Harvard University Press). http://dx.doi.org/10.4159/9780674287013

Blanden, J., Goodman, A., Gregg, P. \& Machin, S. (2004), 'Changes in Intergenerational Mobility in Britain', in M. Corak (ed.), Generational Income Mobility in North America and Europe (Cambridge, Cambridge University Press), 122-46. http://dx.doi.org/10.1017/CBO9780511492549.007

Blanden, J., Gregg, P. \& Macmillan, L. (2013), 'Intergenerational Persistence in Income and Social Class: the Effect of Within-group Inequality', Journal of the Royal Statistical Society, Series A, 176: 1-23. http://dx.doi.org/10.1111/j.1467-985X.2012.01053.x

Breen, R. (2004), 'Statistical Methods of Mobility Research', in R. Breen (ed.), Social Mobility in Europe (Oxford, Oxford University Press), 17-35. http://dx.doi.org/10.1093/0199258457.003.0002

Breen, R. \& Luijkx, R. (2004), 'Conclusions' in R. Breen (ed.), Social Mobility in Europe (Oxford, Oxford University Press), 383-410. http://dx.doi.org/10.1093/0199258457.003.0015

Breen, R., Luijkx, R., Müller, W. \& Pollak, R. (2009), 'Non-persistent Inequality in Educational Attainment: Evidence from Eight European Countries', American Journal of Sociology, 114: 1475-521. http://dx.doi.org/10.1086/595951

Breen, R., Luijkx, R., Müller, W. \& Pollak, R. (2010), 'Long-term Trends in Educational Inequality in Europe: Class Inequalities and Gender Differences', European Sociological Review, 26: 31-48. http://dx.doi.org/10.1093/esr/jcp001

Bukodi, E. (2016), 'Cumulative Inequalities over the Life-course: Life-long Learning and Social Mobility in Britain', Barnett Papers in Social Research, 16-02, Department of Social Policy and Intervention, University of Oxford.

Bukodi, E. \& Goldthorpe, J. H. (2009), 'Class Origins, Education and Occupational Attainment: Crosscohort Changes among Men in Britain', Working Paper 2009/3, Institute of Education, Centre for Longitudinal Studies, London.

Bukodi, E. \& Goldthorpe, J. H. (2011), 'Class Origins, Education and Occupational Attainment in Britain: Secular Trends or Cohort-specific Effects', European Societies, 13: 347-75. http://dx.doi.org/10.1080/14616696.2011.568259

Bukodi, E. \& Goldthorpe, J. H. (2016), 'Educational Attainment—Relative or Absolute - as a Mediator of Intergenerational Class Mobility in Britain, Research in Social Stratification and Mobility, 43: 5-16. http://dx.doi.org/10.1016/j.rssm.2015.01.003

Bukodi, E., Goldthorpe, J. H., Waller, L. \& Kuha, J. (2015), 'The Mobility Problem in Britain: New Findings from the Analysis of Birth Cohort Data', British Journal of Sociology, 66: 93-117. http://dx.doi.org/10.1111/1468-4446.12096 
Bukodi, E., Goldthorpe, J. H., Joshi, H. \& Kuha, J. (2016), 'Why have Relative Rates of Class Mobility become More Equal among Women in Britain?', typescript, Department of Social Policy and Intervention, University of Oxford.

Bukodi, E., Goldthorpe, J. H. \& Kuha, J. (forthcoming), 'The Pattern of Social Fluidity within the British Class Structure: A Topological Model', Journal of the Royal Statistical Society, Series A.

Chan, T.-W. \& Goldthorpe, J. H. (2007), 'Class and Status: The Conceptual Distinction and its Empirical Relevance', American Journal of Sociology, 72: 512-32. http://dx.doi.org/10.1177/000312240707200402

Erikson, R. \& Goldthorpe, J. H. (2010), 'Has Social Mobility in Britain Decreased? Reconciling Divergent Findings on Income and Class Mobility', British Journal of Sociology, 61: 211-30. http://dx.doi.org/10.1111/j.1468-4446.2010.01310.x

Francis, B. \& Hutchings, M. (2013), Parent Power? Using Money and Information to Boost Children's Chances of Educational Success (London, The Sutton Trust).

Gallie, D. (2000), 'The Labour Force', in A.H. Halsey (ed.) Twentieth Century British Social Trends (London, Macmillan), 281-323.

Goldthorpe, J. H. (1982), 'On the Service Class, its Formation and Future', in A. Giddens \& G. Mackenzie (eds.), Social Class and the Division of Labour (Cambridge, Cambridge University Press), $162-85$.

Goldthorpe, J. H. (1987), Social Mobility and Class Structure in Modern Britain, 2nd edn, (Oxford, Clarendon Press).

Goldthorpe, J. H. (2007), On Sociology, 2nd edn, 2 vols (Stanford, CA, Stanford University Press).

Goldthorpe, J. H. (2013), 'Understanding - and Misunderstanding - Social Mobility in Britain: The Entry of the Economists, the Confusion of Politicians and the Limits of Educational Policy', Journal of Social Policy, 42: 431-50. http://dx.doi.org/10.1017/S004727941300024X

Goldthorpe, J. H. \& Jackson, M. (2008), 'Education-based Meritocracy: The Barriers to its Realisation', in A. Lareau \& D. Conley (eds), Social Class: How Does it Work? (New York, Russell Sage Foundation), 93-117.

Goldthorpe, J. H. \& McKnight, A. (2006), 'The Economic Basis of Social Class', in S. Morgan, D. B. Grusky \& G. S. Fields (eds), Mobility and Inequality: Frontiers of Research from Sociology and Economics (Stanford CA, Stanford University Press), 109-36.

Goldthorpe, J. H. \& Mills, C. (2004), 'Trends in Intergenerational Class Mobility in Britain in the Late Twentieth Century', in R. Breen (ed.), Social Mobility in Europe (Oxford, Oxford University Press), 196-224. http://dx.doi.org/10.1093/0199258457.003.0008

Goldthorpe, J. H. \& Mills, C. (2008), 'Trends in Intergenerational Class Mobility in Modern Britain: Evidence from National Surveys, 1972-2005', National Institute Economic Review, 205: 83-100. http://dx.doi.org/10.1177/0027950108096591

Gugushvili, A., Bukodi, E. \& Goldthorpe, J. H. (2016), 'Glass Floor and Glass Ceiling: The Role of Meritocratic and Non-meritocratic Factors in Intergenerational Class Mobility in Britain', ISA Research Committee on Social Stratification and Mobility, Bern.

Hakim, C. (2000), Work-Lifestyle Choices in the 21st Century: Preference Theory (Oxford, Oxford University Press).

Halsey, A. H. (2000), 'Further and Higher Education', in A. H. Halsey (ed.) Twentieth Century British Social Trends (London, Macmillan), 221-53.

Hirsch, F. (1977), Social Limits to Growth (London, Routledge).

Jackson, M., Goldthorpe, J. H. \& Mills, C. (2005), 'Education, Employers and Class Mobility', Research in Social Stratification and Mobility, 23: 3-34. http://dx.doi.org/10.1016/S0276-5624(05)23001-9

Jonsson, J. O \& Mills, C. (1993), 'Social Class and Educational Attainment in Historical Perspective: A Swedish-English Comparison', British Journal of Sociology, 44: 213-47, 403-28 http://dx.doi.org/10.2307/591810 
Kahneman, D. (2011), Thinking Fast and Slow (London, Allen Lane).

Marshall, T. H. (1950), Citizenship and Social Class (Cambridge, Cambridge University Press).

McGovern, P., Hill, S., Mills, C. \& White, M. (2008), Market, Class, and Employment (Oxford, Oxford University Press).

Nicoletti, C. \& Ermisch, J. (2007), 'Intergenerational Earnings Mobility: Changes across Cohorts in Britain', The B.E. Journal of Economic Analysis and Policy, 7: 1-36.

Office for National Statistics (2005), The National Statistics Socio-Economic Classification: User Manual (London, Palgrave-Macmillan).

Paterson, L. \& Ianelli, C. (2007), 'Patterns of Absolute and Relative Social Mobility: A Comparative Study of England, Wales and Scotland', Sociological Research Online, 12(6): 15. http://dx.doi.org/10.5153/sro.1637

Pearson, H. (2016), The Life Project: The Extraordinary Story of 70,000 Ordinary Lives (London, Allen Lane).

Rose, D. \& O'Reilly, K. (eds) 1997, Constructing Classes: Towards a New Social Classification for the UK (Swindon, Office for National Statistics and Economic and Social Research Council).

Rose, D. \& Pevalin, D. (eds) 2003, A Researcher's Guide to the National Statistics Socio-Economic Classification (London, SAGE). http://dx.doi.org/10.4135/9780857024725

Rose, D., Pevalin. D. \& O'Reilly, K. (2005), The National Statistics Socio-Economic Classification: Origins, Development and Use (London, National Statistics and Palgrave-Macmillan).

Routh, G. (1981), Occupation and Pay in Great Britain (Cambridge, Cambridge University Press).

Routh, G. (1987), Occupations of the People of Great Britain (London, Macmillan).

Smith, G. (2000), 'Schools', in A. H. Halsey (ed.) Twentieth Century British Social Trends (London, Macmillan), 179-220.

Spencer, H. (1873), The Study of Sociology (London, King).

Vandecasteele, L. (2016), 'Social Origin, Education and Socio-Economic Inequalities: Trends in the United Kingdom', in F. Bernhardi \& G. Ballarino (eds) Education, Occupation and Social Origin (Cheltenham, Edward Elgar), 215-236. http://dx.doi.org/10.4337/9781785360459.00019

Williams, M. (2013), 'Occupations and British Wage Inequality, 1970s-2000s', European Sociological Review, 29: 41-57 http://dx.doi.org/10.1093/esr/jcs063

Note on the Author: John Goldthorpe CBE, FBA is an Emeritus Fellow of Nuffield College, Oxford and also a Member of the Academia Europaea, a Foreign Member of the Royal Swedish Academy of Sciences, and an Honorary Fellow of the Royal Statistical Society. His main research interests are in the fields of social stratification and mobility and sociological theory and methodology. His most recent book, published in 2016, is Sociology as a Population Science (Cambridge, Cambridge University Press).

john.goldthorpe@nuffield.ox.ac.uk

To cite the article: John Goldthorpe (2016), 'Social class mobility in modern Britain: changing structure, constant process', Journal of the British Academy, 4: 89-111. DOI $10.85871 / \mathrm{jba} / 004.089$ 
This article is licensed under a

Creative Commons Attribution-NonCommercial-NoDerivs 3.0 Unported License.

Journal of the British Academy (ISSN 2052-7217) is published by

The British Academy - the national academy for the humanities and social sciences. 10-11 Carlton House Terrace, London, SW1Y 5AH

www.britishacademy.ac.uk 
